\section{Does the Presence of Sucrose in Pediatric Antibiotics Influence the Enamel Mineral Loss and the Streptococcus mutans Counts in Dental Biofilm?}

Daniela Novaes Soares ${ }^{1}$, Andréa Gonçalves Antonio ${ }^{1}$, Natalia Lopes Pontes Iorio $^{2}$, Viviane Santos da Silva Pierro ${ }^{1}$, Katia Regina Netto dos Santos ${ }^{3}$, Lucianne Cople Maia ${ }^{1}$
'Department of Pediatric Dentistry and Orthodontics, Dental School, UFRJ - Universidade Federal do Rio de Janeiro, Rio de Janeiro, RJ, Brazil ${ }^{2}$ Department of Basic Science, UFF - Universidade Federal Fluminense, Nova Friburgo, RJ, Brazil ${ }^{3}$ Department of Medical Microbiology, Prof. Paulo de Góes Microbiology Institute, UFRJ - Universidade Federal do Rio de Janeiro, Rio de Janeiro, RJ, Brazil

Correspondence: Lucianne Cople Maia, Caixa Postal 68066, Cidade Universitária - CCS, 21.941-971 Rio de Janeiro, RJ, Brasil. Tel: +55-21-25622098. e-mail: rorefa@terra.com.br
The role of antibiotics containing sucrose on the formation of dental caries is still potassium clavulanate suspension), with and without sucrose, on human dental hardness and Streptococcus mutans counts in dental biofilm. Primary tooth fragments $(n=72)$ were coated with nail varnish leaving a window of $2.25 \mathrm{~mm}$ diameter. Specimens were fixed in 24-well polystyrene plates, containing BHI medium. S. mutans (clinical strains) represented the inoculum to form biofilm on the fragments for $24 \mathrm{~h}$. Twelve fragments were separated for the initial count of microorganisms (baseline). The other fragments were divided into 4 groups $(n=12)$ of treatment: $\mathrm{G} 1$ (Clavulin $\left.{ }^{\circledR}\right), \mathrm{G} 2$ (Betamox $\left.{ }^{\circledR}\right), \mathrm{G} 3$ (chlorhexidine 0.12\%), G4 (sucrose 10\%). All specimens had their self-control area (covered area). The cross-sectional microhardness (CSMH) was evaluated for each specimen. All the treated groups had a loss of hardness compared to their self-controls $(p<0.05)$. Both drugs inhibited the S. mutans growth and promoted no CSMH difference among them. Both antibiotics eliminated all formed biofilm and did not cause mineral loss from the enamel, regardless the presence of sucrose in its formulation.

\section{Introduction}

Child antibiotics are frequently administered for the prevention and treatment of bacterial infections. Generally, parents and guardians consider such medicines as the major contributors to the poor dental health of children (1). In fact, some studies show that prolonged use of liquid medicines for children increases the risk of caries in these subjects $(2,3)$, especially due to the concentration of sugars in the medicines (4). However, the influence of these antibiotics in the composition of oral biofilm and the occurrence of caries lesions is still controversial. Some authors have demonstrated the suppressive effect of antibiotics on Streptococcus mutans counts in saliva or plaque (5-7), while others have shown increasing counts of these microorganisms (8), which have an important role in the development of dental caries in humans (9) and in the number of carious lesions (10).

Fukuda et al. (7) conducted a study on children with sickle cell anemia who received long-term prophylactic treatment with penicillin and showed that this drug prevented the build up of $S$. mutans, thus reducing caries in these patients. On the other hand, Dasanayake et al. (8) showed a higher count of this microorganism in children who took antibiotics during the period considered the most critical to acquire S. mutans, which is between 1.5 to 3 years of age, when compared to children who did not take antibiotics in the same period. Moreover, these authors observed a correlation between an increase of S. mutans colonies and caries in these individuals.

Considering that many antibiotics for children are made palatable by the addition of sucrose, glucose or fructose as sweeteners, which may contribute significantly to the dental caries potential in young patients (4) and the conflicting results pointed out either a protective effect or a contributing effect of antibiotics on dental caries, the present study aimed at evaluating if presence of sucrose in pediatric antibiotics influences the enamel mineral loss and S. mutans counts in dental biofilm. The null hypothesis is that the presence of sucrose in pediatric antibiotics formulations does not enhance enamel mineral loss, neither reduce the $S$. mutans counts in dental biofilm.

\section{Material and Methods}

This study was approved by the UFRJ Ethics Committee (protocol \#106/2011).

\section{Selection of Drugs}

Amoxicillin and its combined formulation with potassium clavulanate have been pointed as the most commonly prescribed antibiotics for hospitalized children and for preschool children to treat a variety of infections 
usually by oral administration (11-13). In view of this, two liquid antibiotics for children in the form of oral suspension, Clavulin ${ }^{\circledR}$ (GlaxoSmithKline, Rio de Janeiro, RJ, Brazil) and Betamox $^{\circledR}$ (Laboratórios Atral S.A., Castanheira do Ribatejo, Portugal) were selected for this study. The first does not have sucrose or other sugars in its composition, as observed in a previous study (14), and the second, Betamox ${ }^{\circledR}$, contains sucrose in its composition, as informed by the manufacturer.

\section{Analysis of $\mathrm{pH}$ and Titratable Acidity of Selected Medicines}

The $\mathrm{pH}$ was measured using a digital $\mathrm{pH}$ meter (AM-600; Analion, Ribeirão Preto, SP, Brazil) calibrated with standard solutions. The viscosity was calculated with a viscosimeter (HAAKE RheoStress 600 viscosimeter; Thermo Electron $\mathrm{GmbH}$, Karlsruhe, Germany) and the sucrose concentration of Betamox ${ }^{\circledR}$ was obtained from the Infarmed (National Authority of Medicines and Health Products in Portugal).

\section{Selection and Preparation of Primary Teeth for Biofilm Formation}

Patients from our Pediatric Dental Clinic voluntarily donated exfoliated primary molars in good conditions, magnification. The teeth were sectioned into two pieces: one buccal and one lingual/palatal. From the 80 fragments obtained, 72 were used for the experiment. These specimens were coated with nail polish leaving an exposed area of 2.25 $\mathrm{mm}$ diameter. The coated area served as the control for the fragment itself, as it was not exposed to any treatment.

\section{Inoculum - Streptococcus mutans Biofilm}

The used inoculum consisted of a pool of clinical strains of S. mutans from five (5) volunteers (children) in good general health. The inclusion and exclusion criteria used were based on those proposed by Zero (15), but some modifications were done because the volunteers of this study had caries lesions.

The first step to prepare the inoculum was to isolate the $S$. mutans strains of each volunteer from unstimulated saliva. The saliva collection followed the method proposed by Martins et al. (16). Individually identified salivary samples were placed (dilutions of $10^{0}$ to $10^{-2}$ ) into Petri plates with a selective medium for $S$. mutans (Mitis Salivarius, Difco, Sparks, MD, USA), and incubated for $48 \mathrm{~h}$ at $37^{\circ} \mathrm{C}$ in anaerobic conditions. After incubation, colonies of the microorganisms were quantified $(\mathrm{CFU} / \mathrm{mL})$ per volunteer and stored in tubes containing the culture medium TSB (Tryptic Soy Broth; Oxoid, Hampshire, UK) plus 20\% glycerol.

The stored bacterial samples were placed in $\mathrm{BHI}$ (Brain Heart Infusion) agar (Difco) and incubated at $37^{\circ} \mathrm{C}$ for 48 $\mathrm{h}$ in microaerophilic conditions. Then the samples were transferred to five glass tubes, individually identified, containing BHI broth (Difco). These tubes were incubated at $37{ }^{\circ} \mathrm{C}$ to obtain a bacterial growth with a 0.5 haze on the McFarland scale - around $1.5 \times 10^{8} \mathrm{CFU} / \mathrm{mL}$. The optical density was checked using a spectrophotometer with reading at $625 \mathrm{~nm}$ (Biospectro SP-220 UV-VIS spectrophotometer, Equipar Ltda., Curitiba, Brazil). Finally, $1 \mathrm{~mL}$ of the isolates of each child (from each tube) were put into a single tube to a total volume of $5 \mathrm{~mL}(\mathrm{n}=5)$, resulting in a pool of clinical strains of $S$. mutans.

\section{Characterization of the Inoculum}

The cariogenic potential of each isolated S. mutans strain was identified by evaluating the mineral loss of the dental enamel after biofilm formation in vitro. To do this, 36 bovine enamel blocks with an average initial hardness of $330 \mathrm{kgf} / \mathrm{mm}^{2} \pm 10 \%$ were fixed in polystyrene microtitre 24-well plates with sticky wax and sterilized by ethylene oxide (Bioxxi, Serviços de Esterilização LTDA, Rio de Janeiro, RJ, Brazil).

Thus, in order to produce the S. mutans biofilm of each volunteer on these blocks, as well as from the pool or mixture of clinical strains, the blocks were randomly distributed into 6 groups ( $n=6$ each): (a) biofilm of volunteer 1 , (b) biofilm of volunteer 2; (c) biofilm of volunteer 3; (d) biofilm of volunteer 4, (e) biofilm of volunteer 5 and (f) biofilm of the pool of clinical strains (mixture of five strains).

The culture medium (BHI supplemented with $2 \%$ sucrose, (Difco, $1495 \mu \mathrm{L} /$ well) and the inoculum $(5 \mu \mathrm{L}$ ) were added to each well to a final concentration of $5 \times 10^{5} \mathrm{CFU} /$ $\mathrm{mL}$ to form the biofilms as described above.

This system (plates/blocks) was incubated in microaerophilic conditions for 24 hours at $37^{\circ} \mathrm{C}$, so that the biofilms were formed on the dental blocks. After this, the final surface microhardness test was applied to analyze the cariogenic potential of each biofilm. The percentage of mineral loss was calculated by the following expression:

(Initial microhardness - Final microhardness) x 100 Initial microhardness

Clinical data from prior intra-oral examination $(\mathrm{dmft}$ data) and analysis of salivary flow was also obtained from these volunteers.

\section{In vitro Formation of S. mutans Biofilms on Primary} Tooth Fragments (Main Experiment)

The experimental protocol was carried out according to the methodology used by Antonio et al. (17) and modified by the present authors using a pool of clinical strains of $S$. 
mutans as inoculum. Thus, each primary tooth fragment $(n=72)$ was set in a single well of a polystyrene 24 -well plate with sticky wax. This set of plates/specimens was sterilized with ethylene oxide (Bioxxi). After sterilization, culture medium (BHI supplemented with 2\% sucrose, Difco, 1495 $\mu \mathrm{L} /$ well) was added to each well already containing the inoculum ( $5 \mu \mathrm{L} /$ well - pool of clinical strains of $S$. mutans), giving a final inoculum concentration of $5 \times 10^{5} \mathrm{CFU} / \mathrm{mL}$.

After this procedure, the system was incubated in microaerophilic conditions for $24 \mathrm{~h}$ at $37{ }^{\circ} \mathrm{C}$, so that the biofilm could build up on the dental fragments.

\section{Biofilm Treatment}

After formation of biofilm ( $24 \mathrm{~h}), 12$ fragments from a total of 72 specimens of the primary teeth were removed for the initial S. mutans count as well as for the crosssectional microhardness test, obtaining the baseline values for the study. The remaining fragments $(n=60)$ were divided according to the following treatment groups $(n=12)$ : G1 (Clavulin ${ }^{\circledR}$ oral suspension), G2 (Betamox ${ }^{\circledR}$ oral suspension), $\mathrm{G} 3$ (chlorhexidine $0.12 \%$ - negative control for dental caries formation) and G4 (sucrose solution at 10\% - positive control). In addition to the treated specimens, twelve other fragments that did not receive any treatment, representing the media control (BHI + inoculum).

The treatment took place according to the following protocol: the culture media were removed from each well and then $50 \mu \mathrm{L}$ of each test substance was placed on the surface of the specimens with biofilm for $1 \mathrm{~min}$. Then, the fragments were washed twice with $1500 \mu \mathrm{L}$ of sterile Milli-O water and a fresh medium (BHI, Difco, $1500 \mathrm{uL}$ ) without the inoculum was added to the well. The plate/ specimens/biofilm set was incubated in microaerophilic conditions until the next day, when a new treatment was carried out - always at the same time (once a day). This was repeated for 7 days (Fig. 1).

Microbiological Analysis of the S. mutans Biofilms on the Tooth Fragments and the Acidity of the Medium (Main Experiment)

After 7 days, the tooth fragments were removed from each well and were individually inserted into test tubes containing $1 \mathrm{~mL}$ of saline solution. Then, according to the methodology proposed by Alviano et al. (18) and modified by the present authors, this tube/fragment set was agitated to detach the biofilm. Then $500 \mu \mathrm{L}$ were removed for the biofilm acidity analysis using an appropriate $\mathrm{pH}$-indicator strips (pH 0-14 Universal indicator; Merck KGaA, Darmstadt, Germany).

From the remainder of the suspension, $50 \mu \mathrm{L}$ aliquots were removed for seeding (dilutions of $10^{-1}$ to $10^{-7}$ ), in duplicate, spread over Petri dishes containing $\mathrm{BHI}$ agar
(Difco) for S. mutans counts. The dishes were incubated at $37{ }^{\circ} \mathrm{C}$ for $48 \mathrm{~h}$ in microaerophilic conditions and the results were expressed in $\mathrm{CFU} / \mathrm{mL}$.

\section{Evaluation of Cross-Sectional Microhardness}

At the end of the microbial and acidic analyses of the biofilm, the tooth fragments were removed from the wells, cleaned with tooth brushes and Milli- $\mathrm{Q}$ water; and longitudinally sectioned in the middle of the fragment resulting in two halves. Each half was included in stubs and the cut surfaces were exposed and polished. The crosssectional microhardness was performed using a Digital Microhardness Tester (Micromet 5104; Buehler, Mitutoyo Corporation, Tokyo, Japan) with a load of $25 \mathrm{~g}$ for $10 \mathrm{~s}$. Three sequences of sixteen indentations were made at $10,20,30,40,50,60,70,80,90,100,120,140,160,180$, 200 and $300 \mu \mathrm{m}$ from the outer enamel surface, $150 \mu \mathrm{m}$ apart. The means were calculated for each distance, for both the experimental area and for the control of the fragment itself, featuring a paired analysis. The examiner was blinded for the experiment. The data were expressed as Knoop hardness number $\left(\mathrm{kg} / \mathrm{mm}^{2}\right)$. The schematic design of the used methodology is shown in Figure 1.

\section{Statistical Analysis}

Data were analyzed using SPSS version 17.0 (SPSS Inc., Chicago, IL, USA). The Shapiro-Wilk test was used to verify the normal distribution of the results. Considering the microbiological data and the cross-sectional microhardness values, the Kruskal-Wallis test was used to verify whether there was any statistical difference among the treatment groups and then the groups were compared two by two by the Mann-Whitney test. Since each specimen had its own control (self control), the nonparametric Wilcoxon test was used for the following pairwise comparisons: baseline versus its own control; treatment groups versus their respective self controls; and media control versus its own control. For all analyzes a significance level of 5\% was considered.

\section{Results}

Considering the analysis of $\mathrm{pH}$ and titratable acidity of selected drugs, the characterization of the drugs is shown in Table 1.

With regards to the volunteer characterization, results for the dmft, salivary flow and S. mutans counts for each subject are shown in Table 2. The lower number of $S$. mutans colonies from volunteers 4 and 5 were those who presented higher salivary flow and lower $\mathrm{dmft}$.

Concerning the characterization of the inocula (previous experiment), there was a statistical difference in mineral loss among the different groups of tooth fragments covered with each volunteer's biofilm. However, the biofilm formed 
by the pool of clinical strains group showed no statistically significant difference when compared with other subject groups (Table 3).

Considering the microbiological analysis of the $S$. mutans biofilms on the tooth fragments and the acidity of the medium (main experiment), the baseline group showed the lowest $\mathrm{pH}$ values. Both antibiotics completely eliminated all biofilm microorganisms. The acidity and microbiological counts of the biofilm are shown in Table 4.

In the evaluation of cross-sectional microhardness (main experiment), all treatment groups showed mineral loss when compared to their respective self-controls after the treatment period $(p<0.05)$ but none of them showed mineral loss when compared to the baseline values ( $p>0.05$ ). Sucrose and media control had the highest microhardness losses compared to the antibiotics and to chlorhexidine (Mann
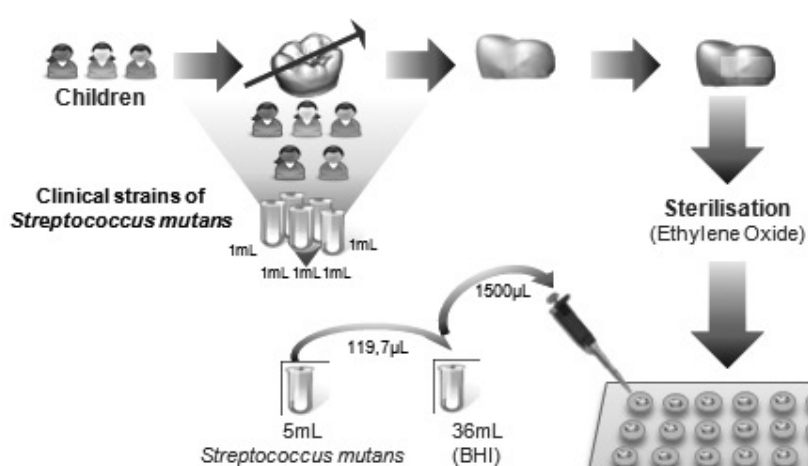

$\left(1,5 \times 10^{8} \mathrm{CFU} / \mathrm{mL}\right)$

BHI)

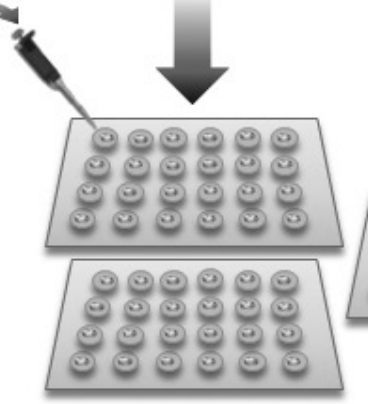

$50 \mu \mathrm{L} /$ well, once a day

during a week

Chlorhexidine

$(0,12 \%)$

Clavulin@

Betamox@

BHI ใै
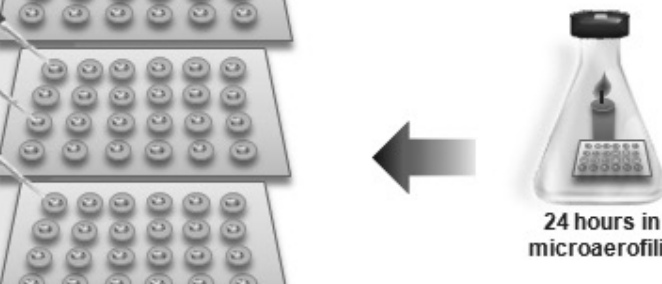

(1)

Baseline

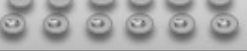

24 hours in microaerofilia $n=12$
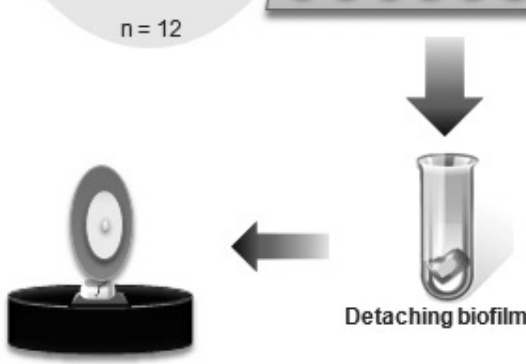

Detaching biofilms
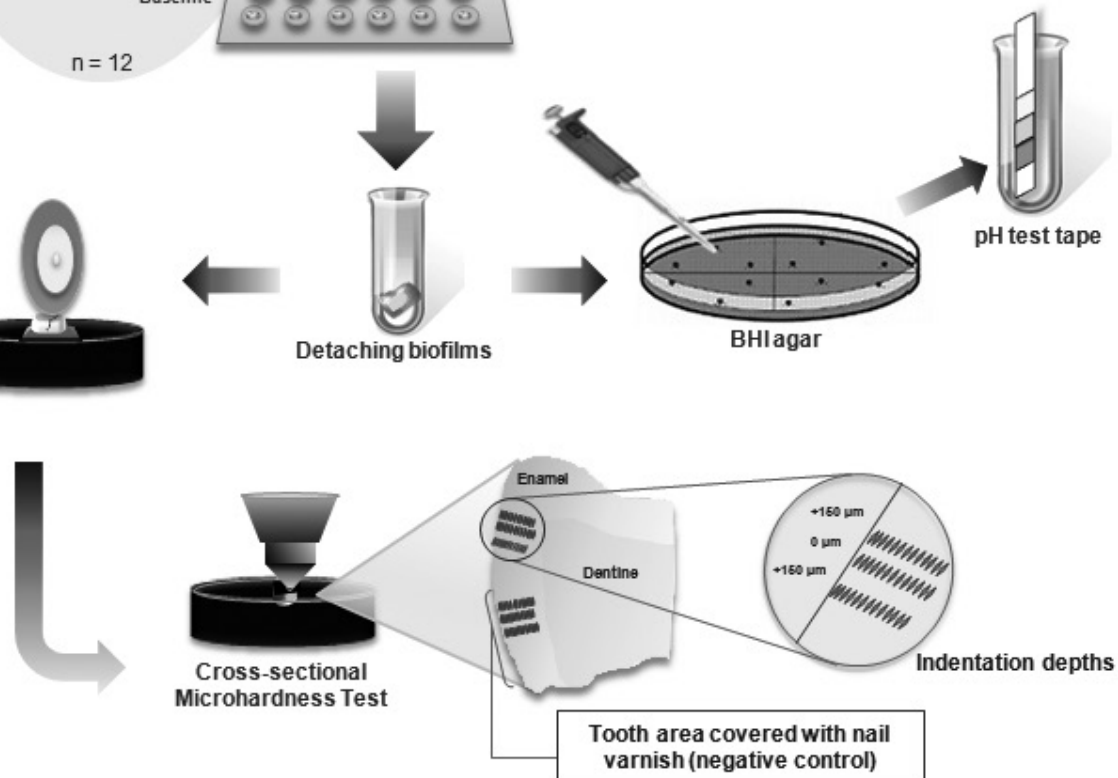

Figure 1. Schematic design of the experimental protocol with primary teeth and the tests used. 
Whitney, $\mathrm{p}<0.05)$. Figures 2 and 3 show the microhardness results of the different treatment groups.

\section{Discussion}

In the literature, there are many in vitro models for caries lesions formation (19-22). Among them the $\mathrm{pH}$-cycling models, which present a disadvantage due to absence of microorganisms, focusing only on the physical-chemical dissolution of enamel (22). Teeth show what occurs in the oral cavity more clearly and, in most cases, they are used in the form of blocks or polished discs (17). However, it is recommended that for biofilm formation the tooth and the substrate be similar to what is found in the oral environment. Thus, this study used primary teeth in natura (without polishing) in a caries formation model with biofilm microorganisms and a culture medium enriched with sucrose.

Since S. mutans is the main etiological agent of dental caries, and it is able to make the biofilm more cariogenic in the presence of sucrose (23), the authors chose to use clinical strains of this bacterium as the inoculum for biofilm formation on tooth fragments. In addition, as this microorganism is found in greater quantities in patients with caries lesions than in patients without caries lesions, children with caries ( $\mathrm{dmft}$ between 8 and 16) were chosen to obtain the $S$. mutans strains (24).

The biofilm formation model proposed by Oliveira et al. (25) used a standard strain of S. mutans. In the present study, were used clinical strains of this bacterium and also a pool of clinical strains in order to reproduce a more diverse biofilm, which could be theoretically more virulent. This decision was based on the different individual characteristics in

Table 1. Characteristics of the studied medicines

\begin{tabular}{lcc}
\hline Characteristics & Clavulin $^{\circledR}$ & Betamox $^{\circledR}$ \\
\hline $\mathrm{pH}$ & 4.67 & 4.68 \\
Titratable acidity $(\mathrm{mmol} / \mathrm{mL}, \mathrm{NaOH} 0.1 \mathrm{M})$ & 0.05 & 0.06 \\
Sucrose concentration $(\mathrm{mg} / \mathrm{mL})$ & ----- & 24.30 \\
\hline
\end{tabular}

Table 2. Characteristics of the volunteers

\begin{tabular}{lccc}
\hline Volunteers & $\begin{array}{c}\text { Salivary flow rate } \\
(\mathrm{mL} / \mathrm{min})\end{array}$ & $\begin{array}{c}\text { S. mutans count } \\
(\mathrm{UFC} / \mathrm{mL}) \text { mean } \pm \text { SD }\end{array}$ & $\mathrm{dmft}$ \\
\hline 1 & 2.1 & $>10^{6} \pm 0$ & 9 \\
2 & 1.0 & $>10^{6} \pm 0$ & 16 \\
3 & 1.5 & $>10^{6} \pm 0$ & 15 \\
4 & 3.8 & $0.5 \times 10^{4} \pm 1 \times 10^{3}$ & 8 \\
5 & 2.4 & $1.1 \times 10^{4} \pm 0.5 \times 10^{4}$ & 8 \\
\hline
\end{tabular}

terms of carious lesion progression and saliva flow rate. Also, dental biofilm may present $S$. mutans with different genotypes, and therefore have different virulence factors.

Thus, in order to observe the difference between the clinical strains used in this study, and a mixture of them in the biofilm formation and caries progression, a previous experiment was carried out. It considered the hardness of tooth enamel as a measure of the biofilm virulence formed individually and by the pool of the S. mutans strains. The results of this study showed that each individual has a specific pattern of demineralization and there is also no difference between the biofilm formed by the pool and the biofilm from different subjects in terms of mineral loss. Therefore, the pool was used as the main experiment inoculum because the literature shows that different strains of S. mutans have different genomes (26).

In addition, for the formation of an inoculum characterized as a pool from biological material, such as

Table 3. Characteristics of the biofilm formed on bovine enamel, considering the inoculums from each volunteer and also from the pool of $S$. mutans (previous experiment)

\begin{tabular}{lccc}
\hline Volunteers & $\begin{array}{c}\text { Initial hardness } \\
\text { mean } \pm \text { SD }\end{array}$ & $\begin{array}{c}\text { Final hardness } \\
\text { mean } \pm \text { SD }\end{array}$ & $\begin{array}{c}\text { Loss of } \\
\text { hardness } \%\end{array}$ \\
\hline 1 & $326.31 \pm 9.32$ & $90.59 \pm 39.54$ & $72.23^{\mathrm{a}}$ \\
2 & $327.49 \pm 15.39$ & $62.59 \pm 16.82$ & $80.89^{\mathrm{a}, \mathrm{c}}$ \\
3 & $333.79 \pm 18.52$ & $86.19 \pm 36.85$ & $74.17^{\mathrm{a}}$ \\
4 & $321.74 \pm 14.35$ & $44.4 \pm 13.89$ & $86.20^{\mathrm{b}, \mathrm{c}}$ \\
5 & $334.76 \pm 12.80$ & $37.68 \pm 18.47$ & $88.74^{\mathrm{b}}$ \\
Pool & $348.13 \pm 8.60$ & $56.49 \pm 9.97$ & $83.77^{\mathrm{a}}$ \\
\hline
\end{tabular}

Means followed by different letters differ among them at a significance level of $5 \%$.

Table 4. Microbiological analysis of Streptococcus mutans biofilm formed on deciduous tooth fragments and the medium acidogenicity (main experiment)

\begin{tabular}{lcc}
\hline Groups & $\begin{array}{c}\text { Acidogenicity } \\
(\mathrm{pH})\end{array}$ & $\begin{array}{c}\text { Microbiological } \\
\text { Counts }(\mathrm{UFC} / \mathrm{mL}) \\
\text { mean } \pm \mathrm{SD}\end{array}$ \\
\hline Baseline & 4.0 & $0.70 \times 10^{7} \pm 0.40 \times 10^{7} \mathrm{a}$ \\
G1 (Clavulin $\left.{ }^{\circledR}\right)$ & 7.0 & $0.00 \pm 0.00^{\mathrm{b}}$ \\
G2 (Betamox $\left.{ }^{\circledR}\right)$ & 7.0 & $0.00 \pm 0.00^{\mathrm{b}}$ \\
G3 (Chlorhexidine) & 7.0 & $0.54 \times 10^{2} \pm 0.53 \times 10^{2 \mathrm{c}}$ \\
G4 (sucrose) & 5.0 & $1.27 \times 10^{8} \pm 0.60 \times 10^{8} \mathrm{a}$ \\
media control & 5.0 & $1.08 \times 10^{8} \pm 0.58 \times 10^{8} \mathrm{a}$ \\
\hline
\end{tabular}

Means followed by different letters differ among them at a significance level of $5 \%$. 
saliva, 3 to 5 patients are usually enrolled to provide this material $(17,19)$. In the present study, 5 patients with caries lesions were randomly enrolled to supply their saliva for isolation of the $S$. mutans clinical strains.

Oliveira et al. (25) used a biofilm forming model for 10 days with culture medium replaced every $24 \mathrm{~h}$. In the model proposed by Ccahuana-Vasquéz et al. (27), the incubation time for the formation of biofilm, using a standard strain of S. mutans was 5 days. In the present study, the time required for incubation to form the biofilm and initial caries lesions was $24 \mathrm{~h}$. The authors opted for a short incubation time due to (a) the virulence of the microorganisms used and (b) the stage of bacterial growth. A pilot study was carried out in the authors' laboratory (unpublished data) with the same pool of clinical strains as in the present study, in order to form biofilm for a 7 days period. The study showed cavities in all exposed areas, making it impossible to carry out a cross-sectional microhardness analysis. Furthermore, in the initial hours of biofilm formation, the bacteria were in their exponential growth phase, showing a higher activity. This was evidenced by the culture medium acidity, since the removed $\mathrm{BHI}$ media presented a $\mathrm{pH}$ of 4.0 immediately after the biofilm formation.

All treatment groups showed a loss of hardness when compared to their respective negative controls. As the negative controls were not exposed to the environment,
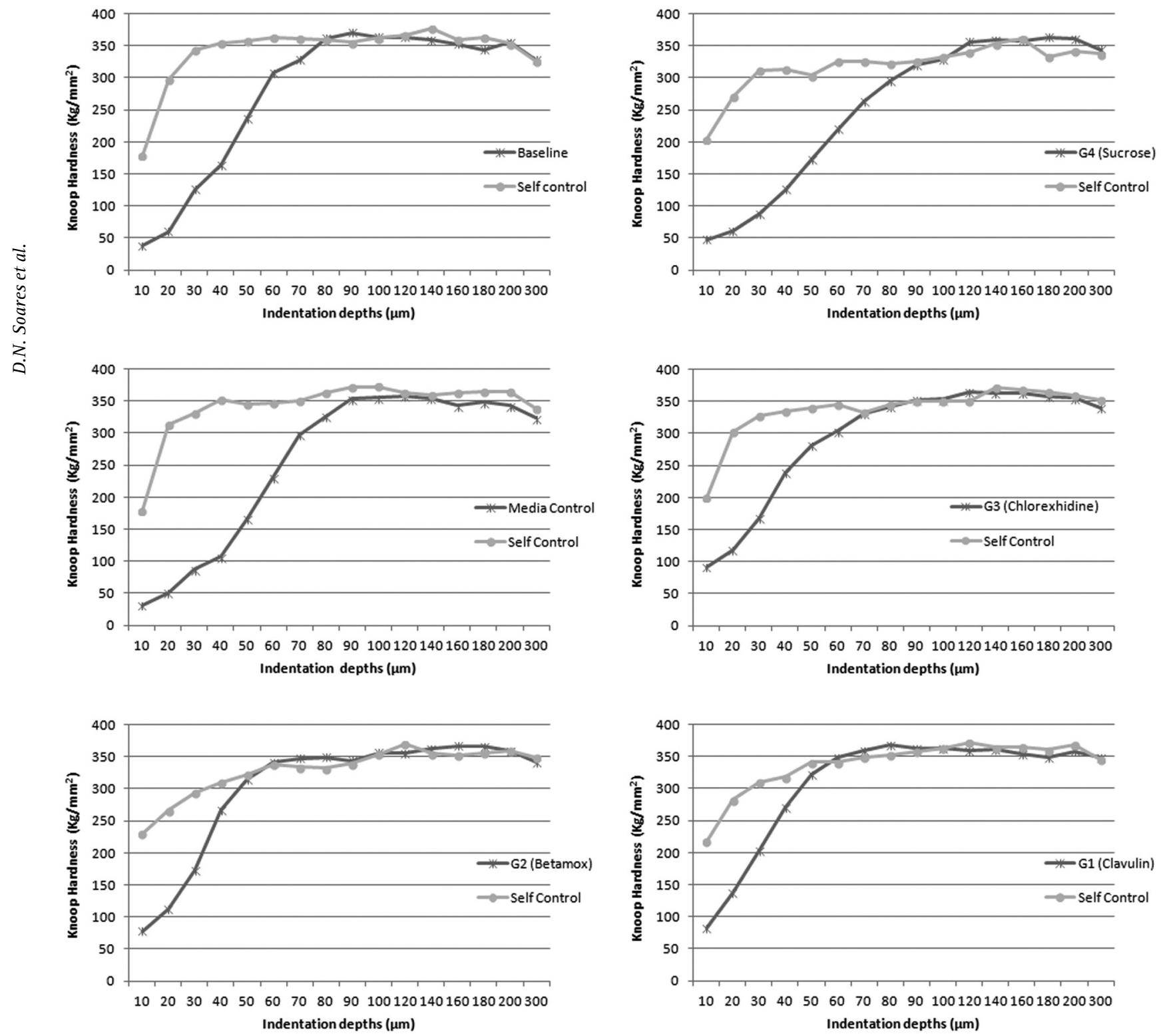

Figure 2. Average values of enamel Knoop hardness $(\mathrm{kg} / \mathrm{mm} 2)$ of the following sets (fragments/biofilm): baseline, media control and treatment groups - G1 (Clavulin $\left.{ }^{\circledR}\right)$, G2 (Betamox $\left.{ }^{\circledR}\right)$, G3 (chlorhexidine) and G4 (10\% sucrose solution) - compared to their respective controls (self controls). All groups showed a loss of hardness when compared with their self-controls (Wilcoxon test, $\mathrm{p}<0.05$ ). 
these results show that the caries lesion formation model proposed by the authors, using a pool of $S$. mutans clinical strains and incubated for only $24 \mathrm{~h}$, was suitable to reproduce caries.

In this study, the lowest $\mathrm{pH}$ values were found soon after the formation of the biofilm before treatment. These values are possibly related to the degradation of sucrose in the medium by the $S$. mutans, leading to formation of organic acids. Sucrose works as a substrate for the synthesis of intracellular and extracellular polysaccharides, increasing the production of acids by microorganisms, and thus the acidity matrix of the biofilm.

However, when comparing the sucrose group (G4) and the baseline group in the present study, it was observed that the enamel demineralization from the sucrose group was not greater than in the baseline group, even though the microbiological results showed a larger S. mutans colony count in $\mathrm{G} 4$. The role of sucrose in the dental decay process is well known but there are few studies about the negative influence of different concentrations of this sugar on biofilm formation processes. Kreth et al. (28) demonstrated that although $S$. mutans use sucrose as a substrate to form the biofilm, there is a toleration limit to the quantity of this substrate. Thus, in the present in vitro study, it was suggested that the amount of used sucrose probably induced a biofilm metabolism alteration, which reduced its formation and consequently its cariogenicity. In addition, the $\mathrm{pH}$ of the biofilm after 7 days of sucrose treatment was greater than the initial $\mathrm{pH}$, that is, despite the increase in bacterial cells, the metabolism of these bacteria was modified within the proposed system, decreasing the production of acids and thus limiting the mineral loss.

One of the reasons for an increase in viable cells in this group (G4), and an enamel demineralization similar

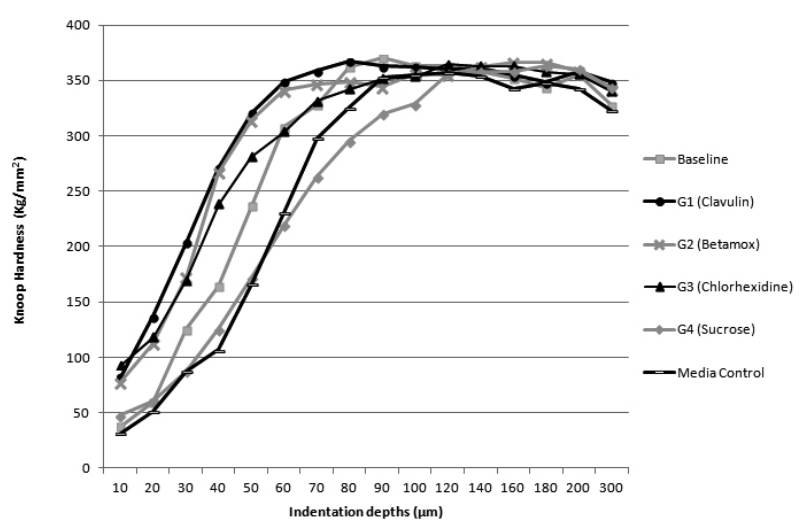

Figure 3. Average values of enamel Knoop hardness ( $\mathrm{kg} / \mathrm{mm} 2)$ for each group. None of the treatment groups showed any mineral loss when compared to baseline ( $p>0.05$ ). The sucrose and media control groups had a greater microhardness loss when compared to the antibiotics and chlorhexidine groups (Mann Whitney, $\mathrm{p}<0.05$ ). to the baseline group, is the intensive growth of bacteria in the first $12 \mathrm{~h}$, followed by a stabilization of the biofilm after this period, since the cells stop multiplying due to increased sucrose synthesis products, such as urea. The "quorum sensing" regulates the physiological process of bacteria since the bacterial cells communicate with each other to coordinate their activities through self-inducing molecules that sense their population density and regulate gene expression to optimize their physiology (29).

The "quorum sensing" is involved in genetic competence, bacitracin production, sporulation, stress responses, virulence expression, biofilm formation, among others (29). This mechanism in S. mutans biofilms demonstrates that this microorganism is unable to metabolize large quantities of sucrose, but after a certain period, stabilizes the mature biofilm in order to maintain its own cells viable. The cells closest to the tooth surface retain their basal metabolism due to the difficulty of oxygen diffusion and nutrient reduction.

Aires et al. (30) showed that concentrations of sucrose over $5 \%$, administered eight times per day, do not have greater ability to demineralize tooth enamel. Since the concentration of sucrose in the antibiotic Betamox ${ }^{\circledR}$ is approximately $20 \%$ and that a concentration of $10 \%$ sucrose is equivalent to a spoonful of sugar commonly used to sweeten $150 \mathrm{~mL}$ of a beverage for infants, it was chosen to use $10 \%$ sucrose as positive control in this study.

The group that was exposed to sucrose daily had similar levels of $\mathrm{pH}$, hardness and also the quantity of bacterial colonies in comparison with the media control, that is, those fragments with biofilm that only received culture medium without addition of sucrose after 7 days of treatment. It should be noted that during the formation of biofilms (the first $24 \mathrm{~h}$ ), this had been supplemented with $2 \%$ sucrose, which made the authors to speculate that this amount of sugar is sufficient for bacterial activity. In addition, the $\mathrm{BHI}$ medium is rich in calcium and phosphorus (17), which probably influenced the trading of minerals with the tooth in both groups, resulting in no further mineral loss.

When the antibiotics Clavulin ${ }^{\circledR}$ and Betamox ${ }^{\circledR}$ are compared neither showed any statistically significant difference considering the microbiological, microhardness and acidogenicity results. These drugs are broad-spectrum antibiotics that act against Gram-positive and Gramnegative microorganisms that are beta-lactamase producers or not. The $S$. mutans organisms used in this study were gram-positive. Therefore, the effect of the main active ingredient (amoxicillin + clavulanate) of the drug was probably bactericidal against $S$. mutans, regardless of the presence of sucrose (7).

The obtained data support the evidence of absence of correlation between the use of antibiotics and the 
development of severe caries lesions, since the hardness of the enamel remained the same before and after treatment with both drugs. Moreover, the results are also in accordance with studies in which the authors observed a decrease of $S$. mutans in the oral cavity after the use of antibiotics $(6,7)$.

Ccahuana-Vasquez et al. (27) showed that the biofilm treatment with chlorhexidine $0.12 \%$, twice daily, was more effective than the use of lower concentrations of this substance, showing its bactericidal effect, since it eliminated almost all viable biofilm bacteria. In the present study, $0.12 \%$ chlorhexidine was applied once daily, but still demonstrated a suppressive effect on microbial counts. However, the $S$. mutans were not completely removed as a small number of $\mathrm{CFU} / \mathrm{mL}$ was found.

This effect can be attributed to the ability of the chlorhexidine molecule to bind onto the surface of the bacterial cell by altering the integrity of the cell membrane, leading to its death, and consequently less enamel demineralizes due to the reduced number of microorganisms (27). This positive effect could be seen in the results after the cross-sectional microhardness analysis, in which there was no loss of hardness after this treatment and with the result of biofilm acidity, which showed an $\vec{s}$ increase in $\mathrm{pH}$, becoming neutral.

When both antibiotics were compared with $0.12 \%$ chlorhexidine, the antibiotics showed a significantly greater bactericidal effect, refuting the null hypothesis. As already mentioned, the antibiotics selected for this study are active against gram-positive and gram-negative bacteria. Chlorhexidine also has a bactericidal activity against the same bacteria. Thus, the result was possibly due to the number of applications i.e., when applied only once daily, chlorhexidine was not able to remove all biofilm bacteria. Even though the microorganisms were not completely eliminated after treatment with chlorhexidine, the $\mathrm{pH}$ value of this group was 7.0, a neutral medium, which is a consequence of the lack of acid production from bacterial activity. In addition, this group did not show any statistical differences in relation to the microhardness and acidity of the medium when compared to the antibiotic groups.

Overall, the results of this study demonstrated that the proposed biofilm formation model was effective for caries reproducibility. Under the tested conditions, it may be concluded that, regardless the presence or absence of sucrose in its composition, both antibiotics were bactericidal against $S$. mutans and did not cause mineral loss in primary enamel.

\section{Resumo}

0 papel dos antibióticos contendo sacarose na formação de cárie dentária é ainda controverso. Este estudo teve como objetivo investigar o efeito de dois antibióticos (amoxicilina / clavulanato de potássio suspensão oral), com e sem sacarose, na dureza do esmalte dental humano e na contagem de Streptococcus mutans no biofilme dental. Fragmentos de dentes decíduos $(n=72)$ foram revestidos com verniz deixando uma janela de exposição de $2,25 \mathrm{~mm}$ de diâmetro. Os espécimes foram fixados em placas de poliestireno de 24 poços, contendo meio de cultura BHI. S. mutans (estirpes clínicas) representaram o inoculo para formar biofilmes sobre os fragmentos por $24 \mathrm{~h}$. Doze fragmentos foram separados para a contagem inicial de microrganismos (baseline). Os restantes dos fragmentos foram divididos em 4 grupos $(n=12)$ de tratamento: $\mathrm{G} 1$ (Clavulin ${ }^{\circledR}$ ), G2 $\left(\right.$ Betamox $^{\circledR}$ ), G3 (clorexidina 0,12\%), G4 (sacarose a 10\%). Todas as amostras tiveram sua área de controle (área coberta). A microdureza transversal (CSMH) foi avaliada para cada espécime. Todos os grupos tratados tiveram uma perda de dureza quando comparados com os seus respectivos controles $(p<0,05)$. Ambos os fármacos inibiram o crescimento de $S$. mutans e não promoveram diferença da CSMH entre eles. Ambos os antibióticos eliminaram todo o biofilme formado, não promovendo assim, perda mineral do esmalte, independente da presença de sacarose na sua formulação.

\section{Acknowledgements}

The authors would like to thank Dr. Karine Caldas Pinto for her technical support. We acknowledge FAPERJ, CNPO and CAPES for the financial support.

\section{References}

1. Neves BG, Pierro VS, Maia LC. Perceptions and attitudes among parents and guardians on the use of pediatric medicines and their cariogenic and erosive potential. Cien Saude Colet 2007;12:1295-1300.

2. Maguire A, Rugg-Gunn AJ, Butler TJ. Dental health of children taking antimicrobial and non-antimicrobial liquid oral medication long-term. Caries Res 1996;30:16-21.

3. McMahon J, Parnell WR, Spears GF. Diet and dental caries in preschool children. Eur J Clin Nutr 1993;47:794-802.

4. Feigal RJ, Jensen ME, Mensing CA. Dental caries potential of liquid medications. Pediatrics 1981;68:416-419.

5. Jordan HV, De Paola PF. Effect of prolonged topical application of vancomycin on human oral Streptococcus mutans populations. Arch Oral Biol 1977;22:193-199.

6. De Paola PF, Jordan HV, Berg J. Temporary suppression of S. mutans in humans through topical application of vancomycin. J Dent Res 1974;53:108-114.

7. Fukuda JT, Sonis AL, Platt OS, Kurth S. Acquisition of mutans streptococci and caries prevalence in pediatric sickle cell anemia patients receiving long-term antibiotic therapy. Pediatr Dent 2005;27:186-190.

8. Dasanayake AP, Roseman JM, Caufield PW, Butts JT. Distribution and determinants of mutans streptococci among African-American children and association with selected variables. Pediatr Dent 1995;17:192-198.

9. Tanzer JM, Livingston J, Thompson AM. The microbiology of primary dental caries in humans. J Dent Educ 2001;65:1028-1037.

10. Alaki SM, Burt BA, Garetz SL. The association between antibiotics usage in early childhood and early childhood caries. Pediatr Dent 2009;31:3137.

11. Pierro VS, Ferreira DC, Jesus HE, Rosado AS, Luiz RR, dos Santos KR, et al.. Topical effect of a medically prescribed pediatric antibiotic on dental biofilm: a cross-over, in situ study. PLoS One 2013; 8:e55558.

12. Piovani $D$, Clavenna $A$, Bonati $M$. Drug use profile in outpatient children and adolescents in different Italian regions. BMC Pediatr 2013;13:46.

13. Sohn $\mathrm{HS}, \mathrm{Oh} \mathrm{OH}, \mathrm{Kwon} \mathrm{JW}$, Lee YS. Higher systemic antibiotic consumption in a population of South Korea (2008-2009). Int J Clin Pharmacol Ther 2013;51:585-592.

14. Neves BG, Farah A, Lucas E, Sousa VP, Maia LC. Are paediatric medicines risk factors for dental caries and dental erosion? Community Dent Health 2010;27:46-51.

15. Zero DT. In situ caries models. Adv Dent Res 1995;3:214-230. 
16. Martins C, Siqueira WL, Oliveira E, Primo LS, Nicolau J. Salivary analysis of patients with chronic renal failure undergoing hemodialysis. Spec Care Dentist 2006;26:205-208.

17. Antonio $A G$, lorio NL, Pierro VS, Candreva MS, Farah A, Santos KR, et al.. Inhibitory properties of Coffea canephora extract against oral bacteria and is effect on demineralization of deciduous teeth. Arch Oral Biol 2011;56:556-564.

18. Alviano WS, Alviano DS, Diniz CG, Antoniolli AR, Alviano CS, Farias LM, et al.. In vitro antioxidant potential of medicinal plant extracts and their activities against oral bacteria based on Brazilian folk medicine. Arch Oral Biol 2008;53:545-552.

19. Soares DN, Antonio AG, Pierro VS, Iorio NL, Santos KR, Maia LC. In vitro effect of paediatric liquid medicines on deciduous enamel exposed to biofilm. Acta Odontol Scand 2013;71:1136-1141.

20. Bueno-Silva B, Koo H, Falsetta ML, Alencar SM, Ikegaki M, Rosalen PL. Effect of neovestitol-vestitol containing Brazilian red propolis on accumulation of biofilm in vitro and development of dental caries in vivo. Biofouling2013;29:1233-1242.

21. Passalini P, Fidalgo TK, Caldeira EM, Gleiser R, Nojima MCG, Maia LC. Preventive effect of fluoridated orthodontic resins subjected to high cariogenic challenges. Braz Dent J 2010;21:211-215.

22. Valinoti $A C$, Pierro VS, Da Silva EM, Maia LC. In vitro alterations in dental enamel exposed to acidic medicines. Int J Paediatr Dent 2011;21:141-150.

23. Struzycka I. The oral microbiome in dental caries. Pol J Microbiol 2014;63:127-135.
24. Koga-Ito CY, Martins CA, Balducci I, Jorge AO. Correlation among mutans streptococci counts, dental caries, and IgA to Streptococcus mutans in saliva. Braz Oral Res 2004; 18: 350-355.

25. Oliveira CS, Maciel FA, Rodrigues LKA, Napimoga MH, Pimenta LAF, Höfling JF, et al.. An in vitro microbial model for producing caries-like lesions on enamel. Braz J Oral Sci 2007;6:1392-1396.

26. Guo LH, Shi JN, Zhang Y, Liu XD, Duan J, Wei S. Identification of genetic differences between two clinical isolates of Streptococcus mutans by suppression subtractive hybridization. Oral Microbiol Immunol 2008;21:372-380.

27. Ccahuna-Vásquez RA, Cury JA. Streptococcus mutans biofilm model to evaluate antimicrobial substances and enamel demineralization. Braz Oral Res 2010;24:135-141.

28. Kreth J, Zhu L, Merritt J, Shi W, Qi F. Role of sucrose in the fitness of Streptococcus mutans. Oral Microbiol Immunol 2008;23:213-219.

29. Syvitski RT, Tian XL, Sampara K, Livingstone N, Jakeman DL, Li YH. Structure-activity analysis of quorum sensing signaling peptides from Streptococcus mutans. J Bacteriol 2007;189:1441-1450.

30. Aires CP, Tabchoury CP, Del Bel Cury AA, Koo H, Cury JA. Effect of Sucrose concentration on dental biofilm formed in situ and on enamel demineralization. Caries Res 2006;40:28-32. 